\title{
A távoktatás lehetősége és szükségessége a pedagógusok továbbképzésében
}

Hercz Mária

A Kodolányi János Fôiskola tudományos munkatársa. Pályáját tanítóként kezdte. 1981-ben részt vett az OPI által szervezett technikatanítási kísérletben, majd az OPI Természettudományi és Technika Osztályának külsổ munkatársaként alsó tagozatos módszertani kiadványokat lektorált. Tanulmányait a József Attila Tudományegyetemen folytatta, ahol 1986-ban pedagógia szakos előadói diplomát szerzett. 1990-tol felsố tagozatban tanított, majd 1997-tốl a Fejér Megyei Pedagógiai Intézetben dolgozott pedagógiai szakértôként. Munkája mellett részt vett a pedagógusok mentálhigiénéjét vizsgáló pályázaton, majd egy nemzetközi projekt résztvevôjeként az európaiságra nevelés lehetốségeit kutatta. Több éven keresztül nevelési vizsgálatokat végzett, a nevelőmunka értékelésének lehetôségeit kutatta. 2001-ben a Szegedi Tudományegyetemen pedagógiai értékelési szakértôi diplomát szerzett, s egyben pedagógus szakvizsgát tett. Jelenleg a BMGE doktori iskolájának hallgatója. Kutatási témája: A pedagógusok gondolkodása a gyermekek kognitív fejlôdésérôl.

\section{Így hivatkozzon erre a cikkre:}

Hercz Mária. „A távoktatás lehetősége és szükségessége a pedagógusok továbbképzésében”. Információs Társadalom III, 2. szám (2003): 101-109.

$=\quad$ https://dx.doi.org/10.22503/inftars.III.2003.2.7 $\rightleftharpoons$

A folyóiratban közölt müvek

a Creative Commons Nevezd meg! - Ne add el! - Így add tovább! 4.0

Nemzetközi Licenc feltételeinek megfelelöen használhatók. 
He rez Mária*

\title{
A távoktatás lehetôsége és szükségessége a pedagógusok továbbképzésében
}

\begin{abstract}
„Annyi bizonyos, hogy az oktatást mindig is a társadalom életfunkciojaként fogták fel, mely úgy marad fenn, hogy generációról generációra átad mindent, amit az emberiség saját magáról megtanult. [...] Az oktatás a rendelkezésünkre álló leghatékonyabb ešköz arra, hogy megformálhassuk a jövốt, vagy - szerényebben fogalmazva - hajónkat a kedvezó áramlatokat követve és a zátonyokat lehetöleg elkerülve a jövó felé kormányozzuk."
\end{abstract}

(Delors 1995)

\section{Az európai oktatás kihívásai}

\subsection{Milyen is lesz a jövô?}

Az elmúlt évtizedben Európa-szerte számos publikáció foglalkozott az iskola megújításának szükségességével. A válságtudat, a nevelés és oktatás eredményességével való elégedetlenség egyidős a pedagógiával (Pukánszky 2001). A kutatók, illetve a különbözô makroszintű elemzések készítőinek munkáiban az elmúlt évtized során ez a kérdés más-más módon merült fel.

Delors a következőképpen látta: „Az oktatás ... állandó és folyamatos jellegű lesz... És kétirányú is lesz, amennyiben egy aktív társadalmon belül minden egyén többször, élete során más-más pillanatban válik tanulóvá és oktatóvá." (Delors 1995:7) Kiemelkedő jelentőségû követelménnyé válik, hogy a fejlődő országok is alakítsák ki a saját szellemi és tudományos elitjüket, s az egész társadalmat egy életen át tartó tanulásra mozgósítsák. Fontos az is, hogy az oktatási rendszerek képesek legyenek alkalmazkodni a társadalmi fejlődéshez. (Delors 1995)

Az OECD 1996-ban fogalmazta meg az élethosszig tartó tanulás követelményét mint új oktatáspolitikai paradigmát. Már 1998-ban felhívta az oktatással foglalkozók figyelmét arra, hogy „a holnap iskolái” csak akkor ốrizhetik meg kulcsszerepüket, ha lényegesen megváltoznak (OECD 1998). 2001-ben az „Investing in Competencies for All” (Beruházás a kompetenciákba mindenki számára) címú tanácskozáson megállapították, hogy bár történtek jelentốs lépések ezen a területen, ezek korántsem elégségesek. Az élethosszig tartó tanulást mindenki számára elérhetôvé kellene tenni, ami a modern informatikai beruházások terén óriási anyagi ráfordítással járna. Az élethosszig tartó tanulás elengedhetetlen feltétele a korszerú tanulási és tanítási

• Kodolányi János Fốiskola, E-mail: hercz@uranos.kodolanyi.hu 
technikák alkalmazása, az Internet és a távoktatás használata. A gazdasági szférával való együttmúköóés nélkül ez nehezen elképzelhetô. A tudásalapú társadalom kialakításának fontos feltétele, hogy a hagyományos alapképzést nyújtó iskolák szellemiségében, a tanárok attitűdjeiben is jelentôs változások menjenek végbe. Megállapították, hogy ezek a feltételek csak akkor teljesülhetnek, ha a tanárok társadalmi megbecsülése és jövedelme is megfelelően emelkedik. Az egyes nemzetek feladatául tűzték ki a tanárképzés és továbbképzés megújítását (OECD 2001).

\subsection{Az oktatás fejlesztése kulcskérdés}

„[Az oktatásnak] egy nehéz viszonyok között álló, szegény országban, amelynek sok elmaradottságot kell behoznia, valósággal újjá kell épülnie; az oktatás és a mûvelődés a legfontosabb prioritások és a legfontosabb befektetések közé tartozik."(Kosáry 1995:4)

A közoktatás kérdései Magyarországon a rendszerváltás óta a politikai és szakmai viták kereszttüzében álltak, a társadalom azonban nem értékelte kellô fontosságúnak őket. A közvéleménykutatások eredményei a 90-es évek elején azt mutatták, hogy ezek a kérdések a középmezônyben, illetve a vizsgált sávok alsó harmadában foglalnak helyet (Medián 1992; Marketing Centrum 1994).

Az OKI Kutatási Központja 1990. és 1995. évi vizsgálataiban arra keresett választ, hogy az emberek mennyire elégedettek a társadalmi közérzetet meghatározó különböző tényezókkel (Halász 1991). A megkérdezettek 66\%-a elégedett volt az oktatással, mely a 3-4. helyet foglalta el a listán. Ez azonban az iskolázottság és a foglalkozás függvénye is volt. Az 1995-ös vizsgálat érdekes eredményt hozott: az emberek véleménye szerint az oktatás színvonala az elôző öt évben javult, egy ötfokozatú skálán azonban csak átlagosan 3,1-es eredményt ért el. Figyelemreméltó, hogy az eltelt időszakban megváltozott a közvélekedés arról, hogy az oktatáson belül mire kellene költeni a pénzt. A közgondolkodásban elkülöníthetố volt egy olyan csoport, mely szerint az állam feladata az élet minőségének javítása, amiben fontos szerepet játszik az oktatás. Figyelemreméltó továbbá, hogy az emberek a továbbtanulásra való felkészítést, az önálló gondolkodásra nevelést, az egyéni képességek fejlesztését várták el leginkább az iskolától (Szabó-Lannert 1996).

\section{A pedagógustovábbképzési rendszer ellentmondásossága}

A közoktatásban a nyolcvanas évektől indultak meg a változások (decentralizáció, az autonómia igényének megnövekedése). Fontos állomás volt az 1985-ben életbe lépett oktatási, majd az 1993. évi közoktatási törvény és az 1995-ben elfogadott NAT. Hiányzott azonban egy átfogó oktatáspolitikai stratégia, melynek megfogalmazására 1996-ban került sor. Ebben a közoktatás fejlesztésének három fổ céljaként a közoktatás modernizálását, a középiskolai oktatás kiterjesztésének támogatását és az erőforrásokkal való gazdálkodás hatékonyabbá tételét jelölik meg. A közoktatás modernizálásának legfontosabb elemei „az oktatás tartalmi modernizációja; az oktatás minôségét biztosító értékelési rendszer fejlesztése, a pedagógus szakma 
erősítése és megújítása és a lemaradókról való fokozott gondoskodás." (Báthory 1996:38).

A pedagógus szakma erôsítésére és megújítására az utóbbi évtizedekben igen sok terv és program született, de ezek megvalósítása rendszeresen megtorpant. A pedagógus-továbbképzésre szánt állami támogatási összegeket a 90-es évek elején a nyelvtanárok átképzésére kellett fordítani. 1995 és 98 között számos pályázati lehetôség segítette a pedagógiai intézeteket, hogy az igényeknek megfelelô területeken ingyenes továbbképzéseket szervezhessenek. Rendszeresen tarthattak ingyenes egynapos intenzív kurzusokat neves előadókkal, például a médiakultúra témakörében.

A támogatási rendszer megváltozásával és a pályázati lehetôségek elapadásával a lehetőségek csökkentek. A pedagógusok továbbképzése leggyakrabban a hiányosságokat pótolja vagy az éppen aktuális oktatáspolitikai feladatokra készít fel. Gondoljunk csak a helyi tantervekre, a pedagógiai programokra, az új tantervek, tankönyvek bevezetésére és a minőségbiztosításra. A tantárgyi, illetve a neveléssel kapcsolatos és a szakmai megújulást segítő tanfolyamokra egyre ritkábban jön össze elegendô számú jelentkezô. A felsố tagozatban vagy középiskolában tanító tanároknak szaktárgyukkal kapcsolatos akkreditált és szervezett továbbképzésre szinte alig van módjuk.

Az okokat felmérve megállapítható, hogy az egyre csökkenő továbbképzési keretből az iskolák a másoddiplomák megszerzését támogatják, a pedagógusok pedig arra törekednek, hogy bejussanak a szakvizsgával egyenértékú képzési formákra. Ez utóbbiak közül azokat részesítik előnyben, amelyek a munkaidejüket kevésbé zavarják - ilyen például a távoktatási formában elvégezhetô közoktatás-vezetối szak. A tartalom megfelelése saját szakmai kívánalmaiknak, illetve intézményük igényeinek gyakran háttérbe szorul, ami ellentmondásba kerül a szakvizsga-rendszer eredeti céljával, a pedagógiai tudás megújításával.

További problémák jelentkeznek a kisiskolákban és a megyeszékhelytôl távolabbi iskolákban. Sok településről csak átszállással, hosszú idő alatt lehet eljutni a képzés helyére. Hiába van a falu autóval egyórányira, a mai pedagógusbérek mellett ezt a tanárok nem vállalják, az iskola pedig nem vállalhatja. A kisiskolákban a helyettesítés gyakran megoldhatatlan.

\section{A távoktatás feltételei az iskolákban}

\subsection{Tárgyi és személyi feltételek}

A pedagógus-továbbképzés megújításának két módja lehet: a képzés ingyenessé tétele és közelebb vitele az iskolákhoz, valamint a távoktatás lehetőségeinek kiaknázása. Az utóbbi természetesnek és egyszerûnek tûnhet mindaddig, amíg a konkrét iskolákat és az ott dolgozó pedagógusokat nem látjuk magunk elôtt. Az elmúlt öt évben egy pedagógiai intézet méréssel és értékeléssel foglalkozó munkatársaként rendszeresen jártam különféle községek és távolabbi települések iskoláiba. Ilyenkor az igazgatók megmutatják iskoláikat, örömmel kiemelve, ha van számítógéptermük, de ha egy kicsit mélyebbre ásunk, rengeteg problémáról is szól- 
nak. A gépek elavultak, nincsenek rendszerbe kötve, gyakran nincs bennük CDmeghajtó, problémát jelent a nyomtató üzemeltetése is. Az Internet-elérési lehetôség ma még sok helyen hiányzik. Ha az iskola igazgatója szívügyének tekinti e kérdéseket, figyeli a pályázati lehetőségeket és képviseli intézménye érdekeit, a tárgyi feltételek javításához többnyire segítséget remélhet a fenntartó önkormányzattól és a minisztériumtól is.

A második legnagyobb gondot mindenütt a szakemberhiány okozza, hiszen az, aki megszerzi a rendszerinformatikus vagy számítástechnika tanári képesítést, a pedagógusbér többszöröséért helyezkedhet el. A pedagógusok egy csoportja kényszerből tanulta meg a számítógép-használatot, mert tantárgyuk óraszáma lecsökkent. Bármilyen jó eredménnyel is végeztek el egy-egy ilyen jellegû́ továbbképzési kurzust, a napi problémák megoldásához nem mindig van kedvük és megfelelố tudásuk. Maguk sem szeretik annyira tantárgyukat, hogy más pedagógusoknak példát mutassanak, meggyőzzék őket a mindennapi alkalmazás hasznosságáról.

„Tapasztalataink szerint az iskolákban a nem informatika szakos tanárok többsége teljesen elzárkózik a számítógépek tanórán való alkalmazásától” - olvassuk Fercsik János és munkatársai egyik konferencia-előadásának összefoglalójában (Fercsik et al. 2001:292). Ók a probléma okát a pedagógusképzésben vélik megtalálni A felsôoktatás hiányosságai valóban fennállhatnak, de nem ez a fố ok. Ha az intézmények tárgyi felszereltségét nézzük, tudomásul kell vennünk, hogy nemcsak szemléletbeli vagy motivációs problémákkal állunk szemben. A gondok elsôdleges oka a tárgyi lehetôségek hiánya. Azokban az iskolákban, ahol a lehetôségek adottak voltak, a pedagógusok megismerkedtek a számítógépekkel és megszerették használatukat.

A könyvtárakban rendelkezésre állnak és kölcsönözhetốk oktatóprogramok CDn, de ezeket többnyire csak a pedagógus tudja megnézni, aki felhívhatja rájuk a gyerekek figyelmét, de nincs módja sem az iskola számára megvásárolni, sem rendszeresen használni őket. Az iskolák többségében a számítástechnikai terem az informatika oktatását is csak úgy tudja megoldani, hogy egy gépnél több gyermek ül, vagy a tanórák délutánra csúsznak át. Nem informatikai tárgyú órát itt tartani a mai állapotok szerint még a középiskolákban is szinte lehetetlen. Mondhatnánk, hogy ezért van a video-projektor és a laptop. Ilyen eszközök azonban alig vannak az iskolákban, ahol pedig megvannak, ott kincsként kezelik őket - mivel az iskola költségvetéséhez képest csakugyan kincsek.

A jövố útja valóban az informatizált oktatás, aminek a tárgyi eszközeit - ha az anyagi feltételeket megteremtik - a pedagógusok ugyanolyan szívesen és aktívan fogják alkalmazni, mint ma az írásvetítôt vagy a videót.

\subsection{A változás lehetôsége}

Amennyiben valóra válik az oktatási miniszter terve, folytatódik az Irisz-SuliNet program, melynek során az összes magyarországi általános iskolát bekötik az Internethálózatba, s ha tovább folytatódik a pedagógusok számítógéphez juttatásának programja, amit ECDL vizsgához kötnek, megváltozhat az iskolák tanulási környezete, ami viszont az oktatás fejlődésének a feltétele.

Az iskolák tanulási környezetének átalakítása különféle modellek alapján lehet- 
séges, a kérdést azonban csak rendszerszemlélettel érdemes vizsgálni. „A rendszerszemlélet a következőkben nyilvánul meg: (1) Egy olyan többszintû stratégiai rendszer elemeként vizsgáljuk az iskolákat, amelynek a programja a tudásalapú gazdaság, illetve az információs társadalom európai modelljének megvalósítására törekszik. (2) Az egész életre kiterjedô tanulás társadalmi programjában az iskolát olyan rendszerintegráló tényezőnek tekintjük, amely tudatosan integrálja a tanulás formális, nemformális és informális komponenseit. (3) A tanulási folyamat hatékonyságát növelô, optimális hatásrendszerben szervezve alkalmazhatjuk az iskola tanulási környezetében a különböző médiumokat az elektronikus információtechnikai eszközök célirányos felhasználásával" (Kis-Tóth-Komenczi 2001:293).

Ezeket a szempontokat figyelembe véve a pedagógus-továbbképzés rendszerének, tartalmának és elérhetôségének reformja létkérdés. A tanárok csak akkor tudnak aktívan közremúködni az informatizált oktatási környezet megteremtésében és továbbfejlesztésében, ha saját élményeik alapján maguk is tapasztalják az ebbôl adódó rendkívüli lehetôségeket.

Az általános iskolai tanulók arra szocializálódnak, hogy a számítógép jó játék, az Interneten is föként a szórakoztató oldalakat keresik. A középiskolás és a felsôoktatásban tanuló diákok többsége tud élni a számítógép és az Internet adta lehetôségekkel, tanáraik azonban nem tudják elképzelni sem, milyen okos és nevelô hatású feladatok adhatók a gyermekeknek, hiszen maguk sem tanultak még ilyen módon.

\section{A távoktatás lehetősége a pedagógus-továbbképzésben}

\subsection{Nyitott képzés és távoktatás a pedagógusok esélyegyenlóségéért}

A mai magyar pedagógus-társadalom rendkívül differenciált. Az intézmények között fennálló hierarchiából, a településszerkezetból és a családok szocio-ökonómiai státuszából adódó különbségek rendkívül jelentôsek. Ha a továbbképzésben résztvevő pedagógusok összetételét vizsgáljuk, kiderül, hogy a magasabb szintû́ kurzusokon nagyobb gyakorisággal vesznek részt a városi vagy nagyvárosi, a magasabb iskolafokozatban dolgozó, valamint a jobb körülmények között élő tanárok. A pedagógusok közötti státuszkülönbségekrôl, a „hátrányos helyzetû” pedagógusokról nem szól a szakirodalom, problémáikat fel sem ismerte az oktatásügy, nemhogy azoknak az orvoslására lépéseket tudna tenni. Pályázati lehetôségek természetesen vannak, de ezek el sem jutnak bizonyos iskolákba, bizonyos pedagógusrétegekhez. Szinte hihetetlen a példa, de a számítógéphez jutáshoz és az Internet-elérés fejlesztéséhez szükséges pályázatok az elmúlt két évben az Interneten jelentek meg, az úrlapok innen voltak letölthetők! Mire az újságokban közölték a lehetőségeket, a pályázni szándékozó, kistelepülésen élő pedagógus és az iskola kifutott az idốból. Sok olyan iskolát is ismerünk, ahol a pedagógusok nem tudták az önrészt, illetve a tanfolyami kötelezettséget vállalni.

Amikor „a” pedagógusok és az informatika kapcsolatáról olvasunk, úgy tünik, mintha egy egységes csoportról lenne szó, holott távolról sem ez a helyzet. A fenti példák is bizonyítják, hogy nem lehet egységes stratégiát kidolgozni a változtatásokra, 
de kutatási és oktatáspolitikai szinten is feltétlenül szükség lenne a gyors és hathatós segítségre.

A nyitott képzés és továbbképzés egyenlő esélyeket teremthetne, s ekkor a programokba való bekapcsolódás valóban csak a pedagógusok elhatározásától függne.

\subsection{A távoktatás legfontosabb jellemzói}

A Mûegyetemi Távoktatási és Felnőttképzési Központ 2002-ben az alábbiak szerint foglalta össze a távoktatás legfontosabb jellemzőit:

- magas költséghatékonyság: összköltsége lényegesen kisebb a hagyományos képzésénél;

- as otthoni tanulás lehetösége: a tanulás üteme, időbeosztása, helye a résztvevőtoól függ;

- relevancia: a tananyagok a felhasználói igények szerint készülnek, elméleti és gyakorlati ismeretek átadására is alkalmasak, a hatékonyság és a személyes motiváció jobban érvényesülhet;

- minőség: alapkövetelmény a folyamatos minôség-ellenôrzés a tananyag előállításában és az önálló tanulásban, de a tanulmányokat záró vizsgáknál is;

- kiegyenlitett tartalom és színvonal: a tanulás és a tanítás hatékonyságát nem befolyásolják a résztvevők egyéni sajátosságai, lehetőségei és korlátai, „az adott programot elsajátító hallgatók ugyanazt a képzést kapják, ugyanabban az időben és ugyanazon az egyenletesen magas színvonalon" (Múegyetemi Távoktatási és Felnôttképzési Központ 2002).

A fenti jellemzốk világossá teszik, hogy az információs technológiák gyors és színvonalas iskolai terjesztésének feltételeit - és egyben lehetőségét - a pedagógusok széles rétegeinek gyors és színvonalas képzése és továbbképzése biztosíthatja, ami a központi hálózatfejlesztési és technikai feltételek megteremtése után a nyitott képzés, illetve a távoktatás segítségével válhat valósággá.

\subsection{Fejlesztési feladatok}

A változtatás a következő feltételek teljesülése mellett képzelhető el:

- Az iskolák és a pedagógus-továbbképző intézmények számítógép-parkjának bôvítése, megújítása. A jelenleg rendelkezésükre álló infrastruktúra általában nem megfelelő minőségú.

- A pedagógusok számítógépher jutásának biztosítása az iskolában és otthon. Az oktató-nevelố munka mindennapi gyakorlatába csak akkor építhető be a modern információtechnológia, ha a nevelő́k segítő eszközévé válik.

- Továbbképzési lehetőség a pedagógusok számára a számítógépes alapismeretek elsajátítására. Itt a hagyományos és a távoktatási formákat kombináló kurzusokat lehetne kidolgozni. Elképzelhetőnek tartom a teljes mértékben irányított önképzést is, de ehhez a tananyag kifejlesztése valószínúleg olyan magas szintû́ pedagógiai és informatikai tudást és munkát igényelne, ami az elavulás gyorsasága és az idóbeli korlátok miatt nem lenne gazdaságos.

- Internet-használat biztosítása a pedagógusoknak minden iskolában, a számukra 
megfelelő időben. Az információhoz jutás esélyegyenlősége így teremthető meg. Mindenki számára biztosítani kellene „az információról való információ” elérését, hiszen a mai világban ennek stratégiai jelentősége van, eldöntheti a felzárkózást vagy a lemaradást. Az Európa Parlament támogatja azt az elképzelést, miszerint a világhálón tárolt adatokat mindenki számára ingyenesen hozzáférhetővé kell tenni. Ezt a lehetôséget kiemelt fontosságúnak tartják az oktatás, az egészségügy és a kultúra területén (Vámosi 2001).

Valószínúleg megvannak a személyi és tárgyi feltételei annak, hogy a felsőoktatási intézmények és a pedagógiai intézetek olyan honlapokat fejlesszenek ki, amelyek tematikus információ- és hálózati címgyújteményeket tartalmaznak, az intézménystruktúra különbözổ szintjein múködô óvodák, iskolák és kollégiumok adataival. Ennek segítségével az egyes iskolák és pedagógusaik elektronikus kapcsolatba kerülhetnének egymással, egyetemi és föiskolai oktatókkal, valamint szaktanácsadókkal, s elektronikus úton tapasztalatcserére, közös gondolkodásra is lenne módjuk. Számos lehetôség nyílna a szakmai fejlődés és a napi pedagógiai gyakorlat segítésére.

- Módszertani útmutatók készítése az egyes tantárgyak oktatóinak távoktatási formában történố továbbképzéséhez. A jelenlegi továbbképzési rendszerbe viszonylag kevés pedagógus tud bekapcsolódni, az akkreditált tanfolyamok tematikája alapján azonban számos területen kifejleszthetôk lennének a távoktatási tananyagok. Ehhez azonban országos szintú koordinációra és irányító szervezetre lenne szükség, egyrészt az anyagi háttér megteremtése és hatékony múködtetése érdekében, másrészt a párhuzamos fejlesztés elkerülése végett.

A távoktatási tananyagok fejlesztéséhez különbözô végzettségû szakemberek összehangolt tevékenységére van szükség. A fejlesztés során a különböző funkciók szétválnak, így a tananyagok létrehozásában számos specialista vesz részt. Szükség van pedagógiai alkotómunkára (szaktanárok, tananyagfejlesztốk, oktatástechnológusok és pedagógiai szerkesztôk közremúködésére), taneszközgyártásra (a tervezéstől a folyamat-irányítási feladatokon át a kivitelezésig), és megfelelő tanulási segítség (mentorok, konzulensek stb.) biztosítására a tanulók számára (Kovács 1996).

- Rendszeres továbbképzési kurzusok távoktatási formában, amelyeken az egyes szakterületek kutatói a pedagógusokat konkrét szakmai lehetőségekkel, tantárgyi oktatóprogramokkal és Internet-használati módszerekkel ismertetnék meg. A jelenlegi rendszer egyik hiányossága, hogy a hétévenként támogatott, pedagógusonként 120 órás továbbképzési keret nagyon hamar kimerül, s ha figyelembe vesszük a szakvizsgákat és a másoddiplomákat is, elképzelhetô, hogy valaki egy évtizedig nem kerül sorra újból. Gondoljuk tovább: hány évenként avulnak el ma az információk, milyen gyorsan cserélődnek ki a tankönyvek, hogyan fejlődik a módszertan stb.

A másik hiányosság az, hogy nincs szabályozva, milyen jellegú képzéssel kell kitölteni a 120 órás keretet. El lehet végezni egy egészségneveléssel foglalkozó vagy a népi kismesterségek oktatására felkészítô tanfolyamot, az iskolai oktató-nevelő munkához szükséges egyéb területekre vonatkozó tudás pedig közben teljesen elavul.

A távoktatás széles kínálatot biztosíthatna, a hozzáférés korlátlan lehetőségével. 
Az elsajátítás kritériumai s a hozzájuk tartozó vizsgarendszer kidolgozható lenne.

- A számitógéppel segitett tanórák iskolai feltételeinek megteremtése. Az európai színvonalú oktatáshoz szükséges lenne a módszertani megújulás is, ennek azonban jelenleg nem biztosítottak a feltételei.

\subsection{A távoktatás és a technika}

A technika fejlődése számos gyakorlati lehetôséget teremthetne a távoktatás számára. A távoktatás egyik formája az Internetre épülô, levelezố jellegû́ oktatás, a másik módszer a videó-konferencia, ami az élő oktatás közvetítésére szolgál (Szabó 1999). Ez utóbbi az iskolai oktatás és a pedagógus-továbbképzés számos területén igen jól alkalmazható lenne. Elốnye, hogy egy-egy neves elôadó óráin térbeli és teremkapacitási korlátok nélkül bárki részt vehet, aki beiratkozott a kurzusra, és azonnali konzultációra is lehetôség van. Az eltérô helyszíneken lévô hallgatókat egymással is összeköthetjük, nincs szükség utazásra.

A videó-konferenciák gyakorlati megvalósításához számos kérdést kell megoldani: ilyenek például a biztonsági és adatvédelmi kérdések, valamint a résztvevốk anyagi hozzájárulása. A legnagyobb gondot azonban a jelenlegi hálózatok kapacitásának elégtelensége okozza. Ahhoz, hogy a kiépítendő rendszer jól múködjön, nagyobb beruházásokra lenne szükség. Meggondolandó azonban, hogy az egyetemeken, a kutatóintézetekben és a megyei pedagógiai intézetekben - a felhasználók érdekében - érdemes lenne ezeket a fejlesztési feladatokat végrehajtani.

\section{Záró gondolatok}

Cikkemben rá kívántam mutatni a jelenlegi pedagógus-továbbképzési rendszer ellentmondásaira, s az átalakítás halaszthatatlanságára. Hangsúlyoztam, hogy szüksẻges lenne átgondơlni, hogyan lehetne a pedagógusok számára teljes körú esélyegyenlőséggel elérhetôvé tenni a távoktatás adta lehetôségeket.

\section{IRODALOM}

Báthory Zoltán (1996): A magyar közoktatás távlati fejlesztésének stratégiája. Múvelődési és Közoktatási Minisztérium, Budapest.

Delors, J. (1995): Jövőnk egyszerre tûnik ígéretesnek és aggasztónak. "A XXI. század oktatása" Nemzetközi Bizottság jelentése. Új Pedagógiai Szemle XLV/1: 3-13

Fercsik, J., Ósz, R., Király, Z. \& Dudás, N. (2001): Miért nem tud még mindig megfelelni a magyar neveléstudomány az informatikai kihívásoknak?. In: I. Neveléstudományi Konferencia. Az értelem kimüvelése. Program, tartalmi összefoglalók. Magyar Tudományos Akadémia Pedagógiai Tudományos Bizottsága, Budapest.

Halász, G. (1991): Mit vár a társadalom az iskolától? Új Pedagógiai Szemle XLI. 6.

Kis-Tóth, L. - Komenczi, B. (2001): Elektronikus tanulási környezetek modelljei. In: I. Neveléstudományi Konferencia. Az értelem kimüvelése. Program, tartalmi összefoglalók. Magyar Tudományos Akadémia Pedagógiai Tudományos Bizottsága, Budapest. 
Kosáry, D. (1996): Szubjektív megjegyzések az oktatásról. Új Pedagógiai Szemle XLVI/2: 3-9

Kovács, I. (1996): Út az oktatásban? A távoktatás. Budapesti Közgazdaságtudományi Egyetem, Felsőoktatási Koordinációs Iroda, Budapest.

Mû́egyetemi Távoktatási és Felnốttképzési Központ (2002, sz. n.): A nyitott és távoktatásról. http://www.bme-tk.bme.hu/tk/bevezetô.html 2002. 05.30.

OECD (1998, sz. n.): Education at a Glance. Education Policy Analyses. Teachers for Tomorrow's School. OECD, Paris.

OEGD (2001, sz. n.): Investing in Competencies for all. A párizsi miniszteri találkozó anyaga, 2001. április 2-4. http:// www.oecd.org 2002. 05. 16.

1. Pukánszky, B. (2001): Iskolakritika és alternativitás.

http://mars.arts.u-szeged.hu/ pukansky/refregenma.htm 2001. 12. 27.

Szabó, I. - Lannert, J. (1996): Mit várunk az iskolától? Új Pedagógiai Szemle XLVI/9: 46-57.

Szabó, Zs. (1999): A távoktatás és a technika. Tóth A. (szerk.): Híd a jövő felé. Tudományos kutatás. Iskola. Internet. Arisztotelész Stúdium Bt., Budapest.

Tanítani és tanulni. A kognitív társadalom felé.(1996, sz. n.). Az Európai Bizottság és Munkaügyi Minisztérium kiadványa, Budapest

Vámosi, Z. (2001): Szociológia aspektusok. Nyitott rendszerû képzés - Távoktatás - Oktatási segédlet. Felsốoktatási tankönyv. Gábor Dénes Fôiskola, Budapest 